\title{
Effect of surface treatments on the adhesive properties of metallic brackets on fluorotic enamel
}

\author{
Mariana Huilcapi ${ }^{1}$, Ana Armas-Vega ${ }^{1}$, Andres Felipe Millan Cardenas², Lucila Cristina Rodrigues Araujo², \\ Jessica Bedoya Ocampo ${ }^{3}$, Matheus Coelho Bandeca², Fabiana Suelen Figuerêdo de Siqueira², Alessandro Loguercio
}

DOI: https://doi.org/10.1590/2177-6709.25.4.059-067.oar

\begin{abstract}
Objective: To compare the effectiveness of the pretreatment with sandblasting and deproteinization with $\mathrm{NaOCl}$ on bond strength (SBS), in situ conversion degree (CD) of brackets in fluorotic enamel, and enamel etching pattern. Methods: A total of 90 non-carious maxillary premolars were used. The teeth were then assigned to six experimental groups according to: enamel surface (sound and fluorotic enamel); surface treatment (Regular etch with 37\% phosphoric acid [RE]; 5.2\% sodium hypochlorite + phosphoric acid [ $\mathrm{NaOCl}+\mathrm{RE}]$; sandblasting + phosphoric acid [sandblasting $+\mathrm{RE}]$ ). After storage in distilled water $\left(37^{\circ} \mathrm{C} / 24 \mathrm{~h}\right)$, the specimens were tested at $1 \mathrm{~mm} / \mathrm{min}$ until failure (SBS). Enamel-resin cement interfaces were evaluated for CD using microRaman spectroscopy. The enamel-etching pattern was evaluated under a scanning electron microscope. Data from SBS and in situ CD values were analyzed using ANOVA two-away and Tukey test $(\alpha=0.05)$. The enamel etching pattern was evaluated only qualitatively. Results: For sound enamel, RE showed the highest SBS values, when compared to $\mathrm{NaOCl}+\mathrm{RE}$ and Sandblasting $+\mathrm{RE}$ groups $(p<0.01)$. Regarding $\mathrm{CD}$, only $\mathrm{NaOCl}+\mathrm{RE}$ significantly compromised the mean $\mathrm{DC}$, in comparison with other groups $(p=0.002)$. For fluorotic enamel, the Sandblasting $+\mathrm{RE}$ group significantly increased the mean SBS values, in comparison with RE group ( $p=0.01)$ and no significant change was observed for $\mathrm{CD}(p>0.52)$. Conclusions: The application of $\mathrm{NaOCl}$ or sandblasting associated to phosphoric acid improved the SBS of the brackets in fluorotic enamel without compromising the CD of the resin cement, with improving of enamel interprismatic conditioning.
\end{abstract}

Keyword: Orthodontics. Sodium hypochlorite. Dental fluorosis. Conversion degree.

Objetivo: Comparar a efetividade do pré-tratamento com jateamento e desproteinização com $\mathrm{NaOCl}$ na resistência de união (SBS), grau de conversão in situ (GC) dos braquetes metálicos ao esmalte fluorótico e o padrão de condicionamento do esmalte. Métodos: Foi utilizado um total de 90 pré-molares superiores livres de cárie. Os dentes foram divididos em seis grupos experimentais, de acordo com: superfície do esmalte (Esmalte Sadio e Fluorótico); tratamento de superfície (Condicionamento com ácido fosfórico a 37\% [ER]; Hipoclorito de sódio a 5,2\% + ácido fosfórico [ $\mathrm{NaOCl}+\mathrm{ER}$ ]; e jateamento + ácido fosfórico [Jateamento + ER]). Após armazenamento em água destilada $\left(37^{\circ} \mathrm{C} / 24 \mathrm{~h}\right)$, os espécimes foram testados a $1 \mathrm{~mm} / \mathrm{min}$ até a falha (SBS). As interfaces esmalte-cimento foram avaliadas para GC usando espectroscopia micro-Raman. O padrão do condicionamento do esmalte foi avaliado sob microscopia eletrônica de varredura. Os dados da SBS e GC foram analisados utilizando ANOVA dois fatores e teste de Tukey $(\alpha=0,05)$. O padrão de condicionamento do esmalte foi avaliado apenas qualitativamente. Resultados: Para o esmalte sadio, o ER apresentou os maiores valores de SBS, quando comparado aos grupos $\mathrm{NaOCl}+\mathrm{ER}$ e Jateamento + ER $(p<0,01)$. Em relação ao GC, apenas a média do grupo $\mathrm{NaOCl}+\mathrm{ER}$ foi comprometida significativamente em comparação aos outros grupos $(p=0,002)$. Para o esmalte fluorótico, Jateamento + ER aumentou significativamente a média dos valores de SBS, em comparação com o grupo ER $(p=0,01)$ e nenhuma mudança significativa foi observada no GC $(p>0,52)$. Conclusões: A aplicação de $\mathrm{NaOCl}$ ou jateamento associado ao ácido fosfórico melhorou a SBS dos braquetes no esmalte fluorótico sem comprometer o GC do cimento resinoso, com a melhoria do condicionamento interprismático do esmalte.

Palavras-chave: Ortodontia. Hipoclorito de sódio. Fluorose dentária. Grau de conversão.

${ }^{1}$ Escuela Odontologia, Facultad de Ciencias de la Salud "Eugenio Espejo", Universidad UTE (Quito, Ecuador).

${ }^{2}$ Universidade Ceuma, Departamento de Pós-graduação em Odontologia (São Luis/MA, Brazil).

${ }^{3}$ Universidade Estadual de Ponta Grossa, Departamento de Odontologia Restauradora (Ponta Grossa/PR, Brazil).

" The authors report no commercial, proprietary or financial interest in the products or companies described in this article.
How to cite: Huilcapi M, Armas-Vega A, Cardenas AFM, Araujo LCR, Ocampo JB, Bandeca MC, et al. Effect of surface treatments on the adhesive properties of metallic brackets on fluorotic enamel. Dental Press J Orthod. 2020 July-Aug;25(4):59-67.

DOI: https://doi.org/10.1590/2177-6709.25.4.059-067.oar

Submitted: June 19, 2018 - Revised and accepted: April 20, 2019

Contact address: Alessandro D. Loguercio

E-mail: aloguercio@hotmail.com 


\section{INTRODUCTION}

The success of the orthodontic treatment using fixed appliances depends substantially on the enamel-brackets bonding. ${ }^{1}$ Unfortunately, bracket bonding failure during the course of orthodontic treatment is a common complication in daily practice, ${ }^{2}$ and it is associated with emergency appointments, thus prolonging treatment time and promoting discomfort to the patients.

Although bracket bonding failure can occur in sound enamel, a worse adhesion is expected when bonding to fluorotic enamel. Fluorotic enamel is more porous and hypomineralized, with often smaller crystallites. ${ }^{3,4}$ Additionally, it has been reported that the mineralized surface layer contains hydrohyapatite, fluoridated-hydroxyapatite and fluorapatite crystals more acid resistant, ${ }^{5}$ which a significantly higher protein content as compared to normal enamel, ${ }^{3}$ compromising the adequate enamel-bracket bonding.

Thus, alternative treatments to increase the bracket retention in fluorotic teeth are suggested. ${ }^{6}$ One of them is to increase enamel surface roughness applying an intraoral sandblasting ${ }^{7}$ with aluminum oxide particles propelled by air pressure, promoting microscopic conditioning. ${ }^{8,9}$ Other alternative is to apply a deproteinization agent, due to higher amount of organic matrix in fluorotic enamel. ${ }^{3}$ Sodium hypochlorite $(\mathrm{NaOCl})$ solution removes the excess of protein content ${ }^{10}$ and may be a possible strategy to optimize adhesion by removing organic elements of the enamel structure and the biofilm. ${ }^{11}$

Moreover, the conversion of monomer into polymer plays an important role in successful enamelbrackets bonding. ${ }^{12,13}$ The conversion degree of orthodontics resin cement was previously reported; however, the authors ${ }^{12}$ did not evaluate the conversion degree into the adhesive interface especially after sandblasting or deproteinization treatment in fluorotic enamel.

Additionally, both alternatives (sandblasting or deproteinization agent) were not compared in the same study ${ }^{6,14,15}$ in fluorotic enamel. Thus, the aim of the present study was to compare the effectiveness of pretreatment using deproteinization with $\mathrm{NaOCl}$ or sandblasting on shear bond strength; in situ conversion degree of brackets in fluorotic enamel, and enamel etching pattern were also compared

\section{MATERIAL AND METHODS}

\section{Tooth selection and specimen preparation}

Diagnosis of dental fluorosis was made according to the severity using the Thylstrup and Fejerskov index (TFI). ${ }^{16}$ Previously to selection of teeth, two examiners were submitted to training and calibration procedure according to Ermis et al. ${ }^{17}$ A total of 90 non-carious human maxillary premolars were used. Forty-five fluorosed teeth with TFI score of 4 and forty-five with TFI of 0 (without fluorosis), were obtained. The teeth were collected after obtaining the patients' informed consent under a protocol approved by the Ethics Committee Review Board of the Universidade Estadual de Ponta Grossa (2.522.293). The teeth were disinfected in $0.5 \%$ chloramine, stored in distilled water, and used within six months of extraction.

\section{Experimental design and sample size calculation}

Ninety teeth $(45 \mathrm{TFI}=0$ and $45 \mathrm{TFI}=4)$ were then assigned to six experimental groups $(\mathrm{n}=15$ per group; 10 to shear bond strength; 4 to in situ conversion degree, and 1 to enamel etching pattern) according to the combination of the independent variables: enamel surface (sound or fluorotic enamel); surface treatment (regular etch with 37\% phosphoric acid [RE]; 5.2\% sodium hypoclorite [Fórmula \& Ação, São Paulo/SP, Brazil $]+$ phosphoric acid $[\mathrm{NaOCl}+\mathrm{RE}]$; and sandblasting [RONDOflex Plus, Kavo Kerr, Joinville/SC, Brazil] + phosphoric acid [Sandblasting + RE]).

For establishing the sample size, the bond strength values of metallic brackets to fluorotic enamel were considered. According to previous literature, mean and standard deviation of metallic brackets to fluorotic enamel was $11.0 \pm 3.1 .^{6,14,18}$ Using an $\alpha$ of 0.05 , a power of $90 \%$ and a two-sided test, the minimal sample size was 10 teeth in each group in order to detect a difference of $5 \mathrm{MPa}$ among the tested groups.

\section{Bonding procedures}

For shear bond strength (SBS) test, the roots of the 60 teeth were centrally embedded in a polyvinyl chloride tube $(10 \mathrm{~mm}$ high $\times 13 \mathrm{~mm}$ diameter) using a chemically cured acrylic resin (Jet Clássico, São Paulo/SP, Brazil) until two-thirds of the root, with the labial surfaces parallel to the mold base so that 
they would be parallel to the force during the bond test. The buccal surface of each tooth was positioned perpendicularly to the base and the buccal surfaces of the teeth were cleaned and polished with oil- and fluoride-free fine pumice using a slow-speed handpiece, then rinsed with water and dried.

All step-by-step bonding procedures are described in Table 1 according to the respective groups. For all groups, the bracket bonding was made with Orthocem resin cement (FGM Dental Products, Joinville/ SC, Brazil), according to the experimental groups (Table 1). After the surface pretreatment, the enamel surface was etched with $37 \%$ phosphoric acid (Condac 37, FGM Dental Products, Joinville/SC, Brazil) for $30 \mathrm{~s}$, rinsing for $15 \mathrm{~s}$ and air-dry for $30 \mathrm{~s}$. A small amount of the bonding resin was applied to the bracket (BioQuick ${ }^{\circledR}$, Forestadent ${ }^{\circledR}$, Pforzheim, Germany) and positioned on the flat surface and pressed.
The excess of the resin cement was removed with a sharp explorer and light-curing was performed using a LED light-curing unit set at $1000 \mathrm{~mW} / \mathrm{cm}^{2}$ (Valo, Ultradent Products Inc, South Jordan, UT, USA). A radiometer (Demetron L.E.D. radiometer, Kerr, Victoria, Australia) was used to check the light intensity every five specimens.

\section{Shear bond strength testing}

After storage in distilled water for 24 hours at $37^{\circ} \mathrm{C}$, the specimens were attached to a shear-testing device (Odeme Biotechnology, Joaçaba/SC, Brazil) and tested in a universal testing machine (Kratos IKCL 3-USB, Kratos Equipamentos Industriais Ltda, Cotia/SP, Brazil) with a 500-N load cell. Each specimen was positioned in the universal testing machine and a chisel tip was placed onto the bracket-enamel interface. The setup was maintained in

Table 1 - Resin cement (batch number), composition, groups, and application mode.

\begin{tabular}{|c|c|c|c|}
\hline $\begin{array}{c}\text { Resin cement } \\
\text { (batch number) }\end{array}$ & Composition & Groups & Application mode (*) \\
\hline \multirow{3}{*}{$\begin{array}{l}\text { Orthocem } \\
\text { Dental Products } \\
\text { (\# 141217) }\end{array}$} & \multirow{3}{*}{$\begin{array}{c}\text { Resin cement: } \\
\text { BisGMA, } \\
\text { TEGDMA, } \\
\text { methacrylic } \\
\text { phosphatized } \\
\text { monomers, } \\
\text { stabilizer, CQ, } \\
\text { co-initiators, } \\
\text { silicon dioxide } \\
\text { nanometric } \\
\text { loading. }\end{array}$} & $\begin{array}{l}\text { Sound and fluorotic } \\
\text { enamel } \\
\text { (RE) }\end{array}$ & $\begin{array}{l}\text { 1. Apply } 37 \% \text { phosphoric acid (Condac } 37 \text { ) for } 30 \mathrm{~s} \\
\text { 2. Rinse for } 30 \mathrm{~s} \text { and air-dry } \\
\text { 3. Apply small amount of resin cement onto the base of the bracket and set it on position } \\
\text { 4. Remove the excess } \\
\text { 5. Light-cure for } 20 \mathrm{~s} \text { at } 1200 \mathrm{~mW} / \mathrm{cm}^{2} \text { for each margin. }\end{array}$ \\
\hline & & $\begin{array}{l}\text { Sound and fluorotic } \\
\text { enamel }+\mathrm{NaOCl} 5.2 \% \\
(\mathrm{NaOCl}+\mathrm{RE})\end{array}$ & $\begin{array}{l}\text { 1. Actively apply } 5.2 \% \mathrm{NaOCl} \text { for } 1 \mathrm{~min} \\
\text { 2. Apply } 37 \% \text { phosphoric acid (Condac } 37 \text { ) for } 30 \mathrm{~s} \\
\text { 3. Rinse for } 30 \mathrm{~s} \text { and air-dry } \\
\text { 4. Apply small amount of resin cement onto the base of the bracket and set it on position } \\
\text { 5. Remove the excess } \\
\text { 6. Light-cure for } 20 \mathrm{~s} \text { at } 1200 \mathrm{~mW} / \mathrm{cm}^{2} \text { for each margin. }\end{array}$ \\
\hline & & $\begin{array}{l}\text { Sound enamel and } \\
\text { fluorotic enamel + } \\
\text { sandblasting } \\
\text { (Sandblasting + RE) }\end{array}$ & $\begin{array}{l}\text { 1. Sandblasting with } 27-\mu \mathrm{m} \text { aluminum oxide at } 80 \text { psi for } 20 \mathrm{~s} \text { at } 5 \mathrm{~mm} \text { from labial surface } \\
\text { at a } 90^{\circ} \text { angle. } \\
\text { 2. Apply } 37 \% \text { phosphoric acid (Condac } 37 \text { ) for } 30 \mathrm{~s} \\
\text { 3. Rinse for } 30 \mathrm{~s} \text { and air-dry } \\
\text { 4. Apply small amount of resin cement onto the base of the bracket and set it on position } \\
\text { 5. Remove the excess } \\
\text { 6. Light-cure for } 20 \mathrm{~s} \text { at } 1200 \mathrm{~mW} / \mathrm{cm}^{2} \text { for each margin. }\end{array}$ \\
\hline
\end{tabular}

*The materials were applied according to the recommendations of their respective manufacturers.

Bis-GMA = bisphenolglycidyl methacrylate; TEGDMA = triethylenelglycidyl methacrylate; $C Q=$ camphorquinone. 
alignment (resin cement-enamel interface, the chis$\mathrm{el}$, and the center of the load cell) to ensure the correct orientation of the shear forces. The crosshead speed in the compressive mode was set at $1 \mathrm{~mm} / \mathrm{min}$ until failure.

The SBS values $(\mathrm{MPa})$ were calculated by dividing the load at failure by the surface area $\left(\mathrm{mm}^{2}\right)$. After testing, the specimens were examined in an optical microscope (SZH-131, Olympus Ltd, Tokyo, Japan) at 10x magnification, to define the adhesive remnant index (ARI) adhered to the tooth and bracket after bracket debonding. ${ }^{19}$ All teeth were analyzed by the same evaluator. The ARI modified was used to classify the failure modes: score $0=$ no resin cement left on the tooth; score 1 = less than half of resin cement left on the tooth; score 2 = more than half of resin cement left on the tooth; score 3 = all resin cement left on the tooth with distinct impression of the bracket base. ${ }^{19}$

\section{In situ conversion degree (CD)}

Twelve sound enamel teeth and twelve fluorotic enamel teeth were used in this topic. The roots of the teeth were removed by sectioning at the cementoenamel junction. The enamel surface was treated and resin cement build-ups were constructed on the bonded enamel using the same protocols described for the SBS test. After storage of the restored teeth in distilled water at $37^{\circ} \mathrm{C}$ for 24 hours, the resin cement-enamel specimens were longitudinally sectioned across the bonded interface with a low-speed diamond saw (Isomet, Buehler Ltd, Lake Bluff, IL, USA) to obtain two resin-enamel slices.

The resin cement-enamel slices were wet polished with 1500-, 2000- and 2500-grit SiC paper for 15 seconds each. Then they were ultrasonically cleaned for 20 minutes in distilled water and stored in water for 24 hours at $37^{\circ} \mathrm{C}$. The micro-Raman equipment (XploRA ONE ${ }^{\mathrm{TM}}$ Raman microscope, HORIBA Scientific, New Jersey, NY, USA) was first calibrated for zero and then for coefficient values using a silicon sample. The samples were analyzed using a 638-nm diode laser through an x100/0.9 NA air objective. The Raman signal was acquired using a 600-lines/mm grafting centered between 600 and $1800 \mathrm{~cm}^{-1}$, and the employed parameters were $100 \mathrm{~mW}$, spatial resolution of $3 \mu \mathrm{m}$, spectral resolution of $5 \mathrm{~cm}^{-1}$, accumulation time of 30 s, with 5 co-additions.
Spectra were taken at the resin cement-enamel adhesive interface at three dissolver sites for each specimen. Spectra of uncured resin cement were taken as references. The ratio of double-bond content of monomer to polymer in the adhesive was calculated according to the following formula: $\operatorname{DC}(\%)=(1-[\mathrm{R}$ cured $/ \mathrm{R}$ uncured $]) \times 100$, where $\mathrm{R}$ is the ratio of aliphatic and aromatic peak intensities at $1639 \mathrm{~cm}^{-1}$ and $1609 \mathrm{~cm}^{-1}$ in cured and uncured resin cement.

\section{Enamel etching pattern}

The enamel-etching pattern was qualitative evaluated on the enamel surface under scanning electron microscope (MIRA TESCAN, Shimadzu, Tokyo, Japan). For this purpose, sound enamel teeth $(\mathrm{n}=3)$ and fluorotic enamel teeth $(n=3)$ were sectioned in the diagonals across the long axis of the tooth with a water-cooled low-speed diamond saw (Isomet 1000) in order to obtain four enamel specimens. ${ }^{20}$ The enamel specimens were conditioned according to the following groups:

1. Regular etch with 37\% phosphoric acid (RE);

2. $\mathrm{NaOCl}+$ phosphoric acid $(\mathrm{NaOCl}+\mathrm{RE})$;

3. Sandblasting + phosphoric acid (Sandblasting + RE).

The surfaces were then rinsed off with tap water for $30 \mathrm{~s}$ and air dried with an air spray for $5 \mathrm{~s}$. All specimens were dried and dehydrated in a desiccator for 12 hours, and the conditioned enamel surfaces were sputter coated with gold/palladium in a vacuum evaporator (SCD 050, Balzers, Schaan, Liechtenstein). The entire surface of treated enamel was examined under a scanning electron microscope (MIRA TESCAN, Shimadzu, Tokyo, Japan). Photomicrographs of representative surface areas were taken at 5000x magnification.

\section{Statistical analysis}

After evaluation of the normality by the ShapiroWilk test and homoscedasticity of the variances by the Bartlett test (not shown data), data from SBS and in situ CD values were analyzed using two-way ANOVA (enamel surface $v$ s surface treatment) and Tukey post-hoc test at a level of significance of $5 \%$. The enamel etching pattern was evaluated only qualitatively. 


\section{RESULTS}

\section{Shear bond strength testing}

The ARI of all groups showed a higher variability between failures scores (Table 2). The RE group showed higher presence of scores 2 and 3 (90\%) in sound enamel. On the other side, in fluorotic enamel, $90 \%$ of the failures were scored as 0 or 1. In sound enamel, the failure pattern to deproteinization $(\mathrm{NaOCl}+\mathrm{RE})$ showed scores 1 and 2 (50\% each one) for sound enamel, and scores 1 and 3 for fluorotic enamel. When Sandblasting + RE group was evaluated, the failure pattern was $90 \%$ scores 0 for sound enamel and 90\% scores 2 and 3 for fluorotic enamel.

Regarding to two-way ANOVA test of SBS values, the cross-product interaction enamel surface $v$ s surface treatment was statistically significant $(p=0.01$, Table 3$)$. The application of RE group in sound enamel showed the highest and statistically significant SBS value, when compared to all groups $(p=0.01$, Table 3$)$. For sound enamel, both alternative treatment $(\mathrm{NaOCl}+\mathrm{RE}$ and Sandblasting $+\mathrm{RE})$ significant decrease the SBS values $(p=0.01$, Table 3$)$. For fluorotic enamel, the application of $\mathrm{NaOCl}+$ RE, as well as Sandblasting + RE, increased the SBS values, but only significantly when Sandblasting $+\mathrm{RE}$ was compared with ER group ( $p=0.01$, Table 3$)$.

\section{In situ conversion degree (CD)}

Regarding to two-way ANOVA test of CD values, the cross-product interaction enamel surface $v$ s surface treatment was statistically significant ( $p=0.002$, Table 4). The application of RE in sound enamel showed higher and statistically similar CD value when compared to Sandblasting + RE $(p=0.32$, Table 4$)$. For sound enamel, the application of $\mathrm{NaOCl}+\mathrm{RE}$ significantly decreased the CD values $(p=0.002$, Table 4). For fluorotic enamel, the application of $\mathrm{NaOCl}+\mathrm{RE}$ or Sandblasting + RE did not significantly change the $\mathrm{CD}$, in comparison with RE group ( $p>0.52$, Table 4$)$.

Table 2 - Percentage of Adhesive Remnant Index (ARI) according to the each score of the different experimental groups

\begin{tabular}{|c|c|c|c|c|c|c|c|c|}
\hline \multirow{2}{*}{ Groups } & \multicolumn{4}{|c|}{ Sound enamel (ARI) } & \multicolumn{4}{|c|}{ Fluorotic enamel (ARI) } \\
\hline & 0 & 1 & 2 & 3 & 0 & 1 & 2 & 3 \\
\hline RE & -- & 10 & 40 & 50 & 80 & 20 & -- & -- \\
\hline $\mathrm{NaOCl}+\mathrm{ER}$ & -- & 50 & 50 & -- & -- & 20 & 30 & 50 \\
\hline Sandblasting + RE & 90 & 10 & -- & -- & -- & 10 & 40 & 50 \\
\hline
\end{tabular}

$\left.{ }^{*}\right)$ ARI scores: score $0=$ no resin cement left on the tooth; score $1=$ less than half of resin cement left on the tooth; score $2=$ more than half of resin cement left on the tooth; score 3 = all resin cement left on the tooth, with distinct impression of the bracket base.

Table 3 - Mean and standard deviations of the shear bond strength (MPa) values of the different experimental groups

\begin{tabular}{ccc}
\hline RE & Sound enamel & Fluorotic enamel \\
\hline $\mathrm{NaOCl}+\mathrm{ER}$ & $17.3 \pm 2.1^{\mathrm{a}}$ & $9.7 \pm 2.1^{\mathrm{c}}$ \\
\hline Sandblasting + RE & $11.8 \pm 3.2^{\mathrm{b}}$ & $11.7 \pm 2.8^{\mathrm{b} . \mathrm{c}}$ \\
\hline
\end{tabular}

(*) Different letters indicate means statistically different (Two-way ANOVA and Tukey test; $p=0.01$ ).

Table 4 - Mean and standard deviations of the in situ conversion degree (\%) values of the different experimental groups

\begin{tabular}{ccc}
\hline & Sound enamel & Fluorotic enamel \\
\hline $\mathrm{RE}$ & $70.3 \pm 2.8^{\mathrm{a}}$ & $58.0 \pm 2.0^{\mathrm{b}}$ \\
\hline $\mathrm{NaOCl}+\mathrm{ER}$ & $61.2 \pm 1.7^{\mathrm{b}}$ & $57.1 \pm 1.9^{\mathrm{b}}$ \\
\hline Sandblasting + RE & $68.6 \pm 2.1^{\mathrm{a}}$ & $57.3 \pm 2.4^{\mathrm{b}}$ \\
\hline
\end{tabular}

(*) Different letters indicate means statistically different (Two-way ANOVA and Tukey test; $p=0.002$ ). 


\section{Enamel etching pattern}

After qualitative evaluation in sound enamel, the RE promoted a deepest and most organized etching pattern, with a presence of the prism core and an intact prism periphery. After $\mathrm{NaOCl}+\mathrm{RE}$ treatment, a higher dissolution of the mineral content and prism periphery was observed. After Sandblasting + RE, an increase of the surface modification and dissolution on the prism core, with a significant destruction structural of the aprismatic area, was found, when compared with other groups (Fig 1).
According to qualitative evaluation of fluorotic enamel, an increase of the micro-irregularity and porosity was observed independently of the treatment. $\mathrm{NaOCl}+\mathrm{RE}$ and Sandblasting + RE groups increased the dissolution of prism core with improving of interprismatic conditioning (Fig 1). When Sandblasting + RE was applied, the prism peripheries have been partially removed, becoming more pronounced, leaving the prism cores relatively intact (Fig 1).

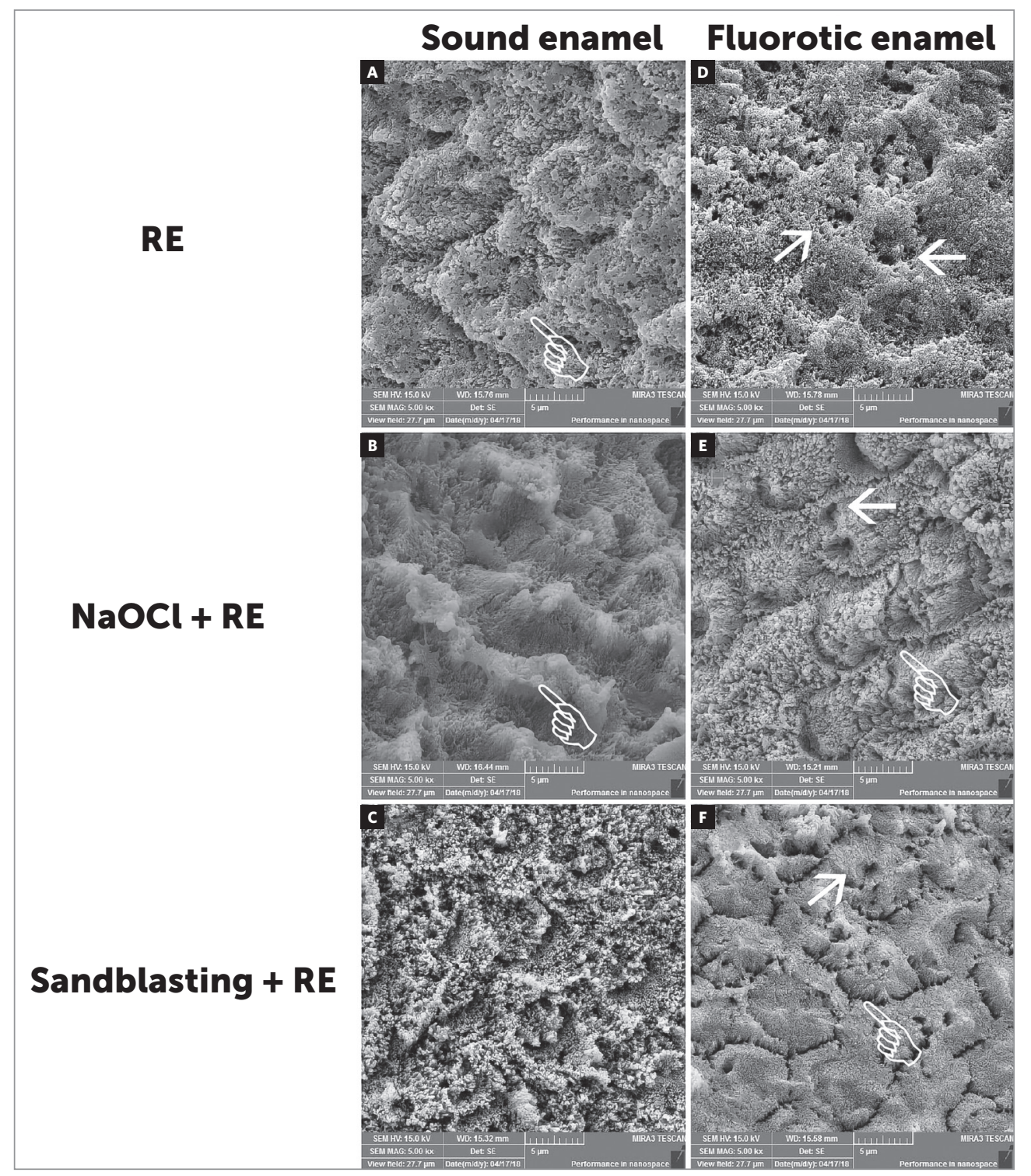

Figure 1 - Representative morphology of sound (A, B, C) and fluorotic enamel (D, E, F) after different treatment. RE resulted in a best-defined etching pattern (white hand, in A). $\mathrm{NaOCl}$ significantly changed the quality of the etching pattern and prism periphery (white hands, in B). Sandblasting promoted a significant structural destruction, with total prism core dissolution (C). Fluorotic enamel showed an increase of the porous number (white arrows in D to F). Better signs of the interprismatic conditioning were observed after treatment in fluorotic enamel (white hands, in $\mathbf{E}$ and $\mathbf{F}$ ). Prism peripheries have been only partially removed (white hand, in F), becoming more pronounced, leaving the prism cores relatively intact (white arrow, in F). 


\section{DISCUSSION}

The results of the present study showed that the application of only phosphoric acid showed the highest bond strength to sound enamel, when compared to fluorotic enamel. It is known that structural differences between normal and fluorotic enamel teeth can influence the bond strength. ${ }^{17,21}$ Dental fluorosis is characterized by a hypermineralized layer, with the presence of fluorapatite in the outer enamel surface more crystalline and stable, making it resists dissolution in acid-etchant. ${ }^{3}$ Thus, these morphological alterations could have promoted the reduction of the bond strength to fluorotic enamel. Additionally, a higher number of ARI scores 0 and 1 was observed in fluorotic enamel, showing the lower interaction with the fluorotic enamel surface in general. On the other side, in the sound enamel, more than 90\% were ARI scores 2 and 3 , showing intense interaction with surface of sound enamel. It is known that a direct correlation between higher ARI score and higher bond strength is expected. ${ }^{22}$

Some reports have suggested that the application of $\mathrm{NaOCl}$ before etching eliminates the organic substances from the enamel surface, and this may increase the bond strength to enamel because it results in an increase in the total conditioning area. ${ }^{11,23}$ On the other hand, several studies have shown that de deproteinization with $\mathrm{NaOCl}$ decreased the bond strength of metallic bracket due to incapacity of improving the quality of the decalcification pattern. ${ }^{24,25}$ The results of the present study are in accordance to Trindade et al, ${ }^{24}$ in which the application of $\mathrm{NaOCl}$ significantly decreased the bond strength to sound enamel. Additionally, it is known that $\mathrm{NaOCl}$ forms reactive free radicals and can inhibit the adequate polymerization. ${ }^{26,27}$ These reactive residual free radicals compete with the propagating vinyl free radicals generated during light activation, resulting in premature chain termination and incomplete polymerization. ${ }^{26}$ Thus, the authors of the present study also speculates that the presence of these residual radicals on the sound enamel decreases the conversion degree inside the enamel-resin cement interface and consequently promotes a reduction of the bond strength values.

However, when $\mathrm{NaOCl}$ was applied on fluorotic enamel, an increase in the bond strength values was observed. It is known that fluorotic enamel contains significantly higher protein content. ${ }^{3}$ Thus, it can be hypothesized that the sodium hypochlorite reacted with the higher protein content present on the fluorotic enamel, ${ }^{3}$ generating less reactive residual free radicals to inhibit the adequate polymerization without compromising the conversion degree. Unfortunately, these results cannot be compared with previously literature, mainly because, to the extent of author's knowledge, this is the first study that evaluated the in situ conversion degree inside the enamel-resin cement-bracket interface. Therefore, future studies are needed to prove this hypothesis.

Regarding the use of sandblasting, controversial results for bond strength values were observed in the literature when sound and fluorotic teeth where compared..$^{9,14,18,28-30}$ It has been suggested that sandblasting of enamel in association with phosphoric acid removes oxides and contaminants from teeth surface, increasing the total energy surface and roughness.' This effect could be partially showed when observing the microscopy evaluation for sound and fluorotic enamel. It could be seen a significant increase of the roughness and porosity existing in both enamel substrates after sandblasting and phosphoric acid, when compared with only phosphoric acid.

However, for sound enamel, the sandblasting decreased the bond strength values when compared to RE group. On the other hand, in fluorotic enamel, a significant increase in the bond strength values occurred when sandblasting was applied. These different results are also showed in the evaluation of the ARI score. A higher number of scores 2 and 3 (90\%) for sandblasting + RE occurred in the fluorotic enamel, meaning that at least more than half of resin cement was left on the fluorotic enamel surface. However, when the sandblasting + RE was applied in the sound enamel, the ARI scores were predominantly 0 and 1 , meaning lower interaction with the sound enamel surface.

Based on these findings, it is inferred that a good interaction between sound enamel and resin cement used after sandblasting application in sound enamel does not occur. It is unclear for the authors of the present study what is the reason for the decrease on bond strength values in sound enamel. However, although exists a common sense that sandblasting has a positive effect in the sound enamel, a recently pub- 
lished systematic review and meta-analysis of in vitro studies showed that the sandblasting did not increase the bond strength values of orthodontic brackets. ${ }^{9}$ However, the extrapolation of these findings is limited because the conclusion was only supported by two in vitro studies. ${ }^{9}$ The lack of standardizing in methodological approaches for different studies could be the reason for the lower number of in vitro studies evaluated in the Baumgartner' study. ${ }^{9}$ Therefore, future better designs and controlled in vitro studies are needed to evaluate the effect of these variables in sound enamel.

Surprising, in fluorotic enamel a significant increase in the bond strength values when sandblasting was applied occurred. These findings are also controversial. ${ }^{14,28}$ As fluorotic enamel is less reactive than sound enamel, it is reasonable to speculate that the microporosities of the fluorotic enamel surface after the application of sandblasting is improved, thus increasing the bonding area $\mathrm{a}^{14,31}$ and, consequently, producing a significant increase of the bond strength values, ${ }^{14,28}$ when compared to only phosphoric acid applied in fluorotic enamel.

It is important to mention the possible limitations in the present study. The results of the present study are based on the immediate results, without any aging method. Commonly, thermocycling is the common method used to evaluate bond durability $y^{32-34}$ and simulate the thermal changes that occur in the oral environment. ${ }^{34}$ However, the varied number of cycles, the choice of temperature, time conditions, and intervals between baths hinder comparison of the results. ${ }^{6,13,34}$ Therefore, further studies should be conducted to investigate if the $\mathrm{NaOCl}$ and sandblasting can preserve the resin cement-fluorotic enamel interface from degradation in longer periods of time.

Thus, the results of the present study suggest that the alternative surface treatment evaluated $(\mathrm{NaOCl}$ or sandblasting) improve the bond strength on fluorotic enamel without compromising the conversion degree of the resin cement used.

\section{CONCLUSIONS}

The application of $\mathrm{NaOCl}$ or sandblasting associated with phosphoric acid improved the bonding of the metallic brackets in fluorotic enamel without compromising the in situ conversion degree of the resin cement. The treatment compromise the bond strength to sound enamel.

\section{Authors' contribution (ORCID ${ }^{(1)}$ )}

Ana Armas-Vega (AAV): 0000-0003-3800-8166 ${ }^{\circ}$

Mariana Huilcapi (MH): 0000-0001-5068-0284 (i)

Andres F. M. Cardenas (AFMC): 0000-0002-7434-3327

Lucila C. R. Araujo (LCRA): 0000-0001-8492-8348

Jessica Bedoya Ocampo (JBO): 0000-0003-1484-8136

Matheus C. Bandeca (MCB): 0000-0002-8099-8821 ${ }^{(0)}$

Fabiana S. F. de Siqueira (FSFS): 0000-0002-1079-3476

Alessandro D. Loguercio (ADL): 0000-0001-9880-4856

Conception or design of the study: AAV, MH, AFMC, LCRA, JBO, MCB, FSFS, ADL. Data acquisition, analysis or interpretation AAV, MH, AFMC, LCRA, JBO, MCB, FSFS, ADL. Writing the article: ADL. Critical revision of the article: AAV, MH, AFMC, LCRA, JBO, MCB, FSFS, ADL. Final approval of the article: AAV, $\mathrm{MH}$, AFMC, LCRA, JBO, MCB, FSFS, ADL. Obtained funding: ADL. Overall responsibility: ADL. 


\section{REFERENCES}

1. Grubisa HS, Heo G, Raboud D, Glover KE, Major PW. An evaluation and comparison of orthodontic bracket bond strengths achieved with selfetching primer. Am J Orthod Dentofacial Orthop. 2004;126(2):213-9: quiz 55.

2. Klocke A, Shi J, Vaziri F, Kahl-Nieke B, Bismayer U. Effect of time on bond strength in indirect bonding. Angle Orthod. 2004;74(2):245-50.

3. Fejerskov $O$, Larsen MJ, Richards A, Baelum V. Dental tissue effects of fluoride. Adv Dent Res. 1994;8(1):15-31.

4. Horowitz HS, Driscoll WS, Meyers RJ, Heifetz SB, Kingman A. A new method for assessing the prevalence of dental fluorosis--the Tooth Surface Index of Fluorosis. J Am Dent Assoc. 1984:109(1):37-41.

5. Robinson C, Connell S, Kirkham J, Brookes SJ, Shore RC, Smith AM. The effect of fluoride on the developing tooth. Caries Res. 2004;38(3):268-76.

6. Zarif Najafi H, Moshkelgosha V, Khanchemehr A, Alizade A, Mokhtar A. The effect of four surface treatment methods on the shear bond strength of metallic brackets to the fluorosed enamel. J Dent (Shiraz). 2015;16(3):251-9.

7. Nergiz I, Schmage P, Herrmann W, Ozcan M. Effect of alloy type and surface conditioning on roughness and bond strength of metal brackets. Am J Orthod Dentofacial Orthop. 2004:125(1):42-50

8. Black RB. Application and revaluation of air abrasive technic. J Am Dent Assoc. 1955:50(4):408-14

9. Baumgartner S, Koletsi D, Verna C, Eliades T. The effect of enamel sandblasting on enhancing bond strength of orthodontic brackets: A systematic review and meta-analysis. J Adhes Dent. 2017;19(6):463-73.

10. Mangum JE, Crombie FA, Kilpatrick N, Manton DJ, Hubbard MJ. Surface integrity governs the proteome of hypomineralized enamel. J Dent Res. 2010;89(10):1160-5

11. Espinosa R, Valencia R, Uribe M, Ceja I, Saadia M. Enamel deproteinization and its effect on acid etching: an in vitro study. J Clin Pediatr Dent 2008:33(1):13-9

12. Amato PA, Martins RP, dos Santos Cruz CA, Capella MV, Martins LP. Time reduction of light curing: Influence on conversion degree and microhardness of orthodontic composites. Am J Orthod Dentofacial Orthop. 2014:146(1):40-6

13. Sena LMF, Barbosa HAM, Caldas S, Ozcan M, Souza R. Effect of different bonding protocols on degree of monomer conversion and bond strength between orthodontic brackets and enamel. Braz Oral Res. 2018;32:e58.

14. Suma S, Anita G, Chandra Shekar BR, Kallury A. The effect of air abrasion on the retention of metallic brackets bonded to fluorosed enamel surface. Indian J Dent Res. 2012:23(2):230-5

15. Sharma R, Kumar D, Verma M. Deproteinization of fluorosed enamel with sodium hypochlorite enhances the shear bond strength of orthodontic brackets: An in vitro study. Contemp Clin Dent. 2017:8(1):20-5.

16. Rozier RG. Epidemiologic indices for measuring the clinical manifestations of dental fluorosis: overview and critique. Adv Dent Res. 1994;8(1):39-55.

17. Ermis RB, De Munck J, Cardoso MV, Coutinho E, Van Landuyt KL, Poitevin A et al. Bonding to ground versus unground enamel in fluorosed teeth. Dent Mater. 2007:23(10):1250-5

18. Brosh T, Strouthou S, Sarne O. Effects of buccal versus lingual surfaces, enamel conditioning procedures and storage duration on brackets debonding characteristics. J Dent. 2005;33(2):99-105

19. Arima VO, Vedovello MF, Valdrighi HC, Lucato AS, Santamaria M, Jr. Vedovello SAS. Debonding forces of different pads in a lingual bracket system. Dental Press J Orthod. 2017:22(4):34-40.
20. Loguercio AD, Munoz MA, Luque-Martinez I, Hass V, Reis A, Perdigao J. Does active application of universal adhesives to enamel in self-etch mode improve their performance? J Dent. 2015:43(9):1060-70.

21. Torres-Gallegos I, G AM-C, Loyola-Rodriguez JP, Patino-Marin N, Encinas A Ruiz F, et al. Effectiveness of bonding resin-based composite to healthy and fluorotic enamel using total-etch and two self-etch adhesive systems. Dent Mater J. 2012;31(6):1021-7.

22. Faria-Junior EM, Guiraldo RD, Berger SB, Correr AB, Correr-Sobrinho L, Contreras EF, et al. In-vivo evaluation of the surface roughness and morphology of enamel after bracket removal and polishing by different techniques. Am J Orthod Dentofacial Orthop. 2015:147(3):324-9.

23. Justus R, Cubero T, Ondarza R, Morales F. A New technique with sodium hypochlorite to increase bracket shear bond strength of fluoride-releasing resin-modified glass ionomer cements: Comparing shear bond strength of two adhesive systems with enamel surface deproteinization before etching. Semin Orthod. 2010;16(1):66-75.

24. Trindade AM, Pereira TBJ, Smith Neto P, Horta MCR, Pithon MM, Akaki E, et al. Consequences of enamel preparation with sodium hypochlorite. polyacrylic and phosphoric acids for the bonding of brackets with resinmodified glass ionomer cements. Mat Res. 2013:16(1):1423-7.

25. Ahuja B, Yeluri R, Baliga S, Munshi AK. Enamel deproteinization before acid etching--a scanning electron microscopic observation. J Clin Pediatr Dent 2010;35(2):169-72

26. Lai SC, Mak YF, Cheung GS, Osorio R, Toledano M, Carvalho RM, et al. Reversal of compromised bonding to oxidized etched dentin. J Dent Res. 2001;80(10):1919-24

27. Dikmen B, Gurbuz O, Ozsoy A, Eren MM, Cilingir A, Yucel T. Effect of different antioxidants on the microtensile bond strength of an adhesive system to sodium hypochlorite-treated dentin. J Adhes Dent 2015;17(6):499-504.

28. Noble J, Karaiskos NE, Wiltshire WA. In vivo bonding of orthodontic brackets to fluorosed enamel using an adhesion promotor. Angle Orthod. 2008:78(2):357-60

29. Robles-Ruiz JJ, Ciamponi AL, Medeiros IS, Kanashiro LK. Effect of lingual enamel sandblasting with aluminum oxide of different particle sizes in combination with phosphoric acid etching on indirect bonding of lingual brackets. Angle Orthod. 2014;84(6):1068-73

30. Daratsianos N, Schutz B, Reimann S, Weber A, Papageorgiou SN, Jager A, et al. The influence of enamel sandblasting on the shear bond strength and fractography of the bracket-adhesive-enamel complex tested in vitro by the DIN 13990:2017-04 standard. Clin Oral Investig. 2018.

31. Chung K, Hsu B, Berry T, Hsieh T. Effect of sandblasting on the bond strength of the bondable molar tube bracket. J Oral Rehabil. 2001;28(5):418-24

32. Yang B, Adelung R, Ludwig K, Bossmann K, Pashley DH, Kern M. Effect of structural change of collagen fibrils on the durability of dentin bonding. Biomaterials. 2005;26(24):5021-31.

33. Dos Santos PA, Garcia PP, Palma-Dibb RG. Shear bond strength of adhesive systems to enamel and dentin. Thermocycling influence. J Mater Sci Mater Med. 2005;16(8):727-32.

34. Amaral FL, Colucci V, Palma-Dibb RG, Corona SA. Assessment of in vitro methods used to promote adhesive interface degradation: a critical review. J Esthet Restor Dent. 2007:19(6):340-53; discussion 54 